\title{
SUATU TINJAUAN ATAS PROSEDUR PENERIMAAN BARANG IMPOR DARI PELABUHAN MUAT DENGAN STATUS PETI KEMAS FULL CONTAINER LOAD (FCL)
}

\section{Nafis Hafiyyan Ahmad, Egi Arvian Firmansyah}

Universitas Padjadjaran, Bandung

A R T I C LE INFO

\author{
Keywords : Customs, CIF, FCL, Freight \\ Forwarding, Import, Incoterms
}

Kata Kunci : Bea Cukai, CIF, FCL, Freight

Forwarding, Impor, Incoterms

Corresponding author :

Nafis Hafiyyan Ahmad

nafishafiyyan200497@gmail.com
Abstrack: This research aims at describing the procedure of receiving imported goods from loading port with container loading status of Full Container Load (FCL) Terms CIF on PPJK PT Glorious Interbuana. This research also aims at exploring the problems contained in the company for future improvement. This research is a case study research using primary data resulted from interview with management and observation in field. We then compared the results in the field with previous research to be analyzed descriptively. The results showed that there were different procedures but not very significant. Some of the problems faced by companies in importing include the changing customs regulations and weak relationships between government ministry agencies and customs. Therefore, continuous improvement of customs is required in order to support import activities in the future.

Abstrak : Penelitian ini bertujuan untuk menggambarkan prosedur penerimaan barang impor dari pelabuhan muat dengan status peti kemas Full Container Load (FCL) Terms CIF Pada PPJK PT Glorious Interbuana. Penelitian ini juga bertujuan menggali permasalahan yang terdapat di perusahaan untuk perbaikan di masa mendatang. Penelitian ini merupakan penelitian studi kasus menggunakan data primer hasil wawancara dengan manajemen dan observasi di lapangan. Kami kemudian membandingkan hasil di lapangan dengan penelitian sebelumnya untuk kemudian dianalisis secara deskriptif. Hasil penelitian menunjukan bahwa terdapat perbedaan prosedur namun tidak terlalu signifikan. Beberapa permasalahan yang dihadapi perusahaan dalam melakukan impor di antaranya adalah peraturan Bea dan Cukai yang berubah-ubah dan lemahnya hubungan antara instansi kementrian pemerintah dengan bea cukai. Sehingga, diperlukan perbaikan terus menerus (continues improvement) pada Bea dan Cukai agar dapat mendukung kegiatan impor di masa mendatang. 


\section{Latar Belakang}

\section{PENDAHULUAN}

Sejak bulan Januari hingga November 2017, Indonesia mengalami peningkatan nilai ekspor sebesar US\$ 153,90 miliar atau sekitar 17,16 persen dibanding pada tahun 2016 dengan periode yang sama. Begitupun juga terjadi pada kegiatan impor yang mengalami kenaikan pada bulan November 2017 sebesar US\$ 15,15 miliar atau sekitar 6,42\% dari bulan Oktober 2017 (Badan Pusat Statistik, 2017). Berdasarkan data tersebut dapat disimpulkan bahwa kegiatan ekspor dan impor tidak dapat dipandang sebelah mata. Walaupun kegiatan ekspor Indonesia mengalami kenaikan, kegiatan impor pun dari bulan ke bulan mengalami kenaikan. Hal ini seharusnya menjadi perhatian pemerintah dalam hal perdagangan internasional.

Tidak hanya terjadi di Indonesia, semua negara di dunia ini pasti akan melakukan interaksi dengan negaranegara di sekitarnya. Biasanya bentuk kerjasama atau interaksi itu berbentuk perdagangan antarnegara atau yang lebih dikenal dengan istilah perdagangan internasional. Salah satu contohnya yaitu negara Tiongkok, kantor berita Reuters melansir bahwa nilai ekspor Tiongkok mengalami peningkatan sebesar 11,1\% dari tahun 2017. Selain itu nilai impor negara Tiongkok mengalami lonjakan sebesar 36,9\% dari bulan Februari 2017. Berdasarkan informasi tersebut dapat dikatakan bahwa negara sekelas Tiongkok yang merupakan salah satu contoh negara pengekspor terbesar di dunia pun masih melakukan kegiatan perdagangan internasional.

Walaupun suatu negara melakukan impor karena mengalami defisiensi dalam memproduksi barang dan jasa bagi kebutuhan rakyatnya. Akan tetapi, impor mempunyai peranan penting terhadap perkembangan industri di dalam negeri khususnya dan terhadap perkembangan ekonomi pada umumnya. Peranan penting impor dapat dilihat dari fungsi impor tersebut dalam perekonomian suatu negara. Fungsi impor adalah untuk pengadaan bahan kebutuhan pokok (barang konsumsi), pengadaan bahan baku bagi industri di dalam negeri, dan untuk pengadaan barang modal yang belum bisa dihasilkan di dalam negeri. Fungsi lainnya adalah untuk merintis pasar domestik, merangsang pertumbuhan industri baru, dan perluasan serta perkembangan industri yang sudah ada. Salah satu cara untuk mengetahui tersedia atau tidaknya pasar bagi suatu komoditas tertentu di dalam negeri adalah dengan melihat aktivitas impor. Impor merupakan indikator bahwa pasar ada karena dari angka impor akan dapat diketahui barangbarang mana yang pasarannya sedang berkembang di dalam negeri.

Untuk memasuki pasar luar negeri tidaklah semudah memasuki pasar domestik, karena aktivitas eksporimpor cenderung memerlukan suatu proses yang panjang dan bertahap. Seperti halnya, eksportir maupun importir yang baru mengenal dunia bisnis internasional pasti mempunyai permasalahan mengenai prosedur pengiriman barang ekspor maupun penerimaan barang impor. Sehingga eksportir dan importir yang baru memasuki pasar internasional dalam pengurusan dokumen administrasi perdagangan internasional dapat menggunakan jasa dari freight forwarding (FF) yang bergerak dalam ekspedisi muatan atau pengiriman barang melalui jalur darat, laut maupun udara (Suyono, 2005).

Adanya aktivitas bisnis internasional ini memberikan tantangan dan peluang kepada perusahaan jasa yang bergerak dalam bidang ekspor dan impor seperti perusahaan Freight Forwarding. Freight forwarding (FF) dapat bertindak sebagai perantara ekportir dengan importir. Freight forwarding juga menyelesaikan biaya-biaya yang timbul akibat dari kegiatan transportasi dan pengurusan administrasi dokumen yang selanjutnya akan dibayar oleh pemberi perintah dan ditambah dengan biaya jasa pelayanan (Suyono, 2005). Selain itu, freight forwarding sangat fleksibel dalam menerima dan membantu eksportir maupun importir dalam melakukan perdagangan internasional (Suyono, 2005). Sehingga eksportir maupun impotir bisa menggunakan jasa freight forwarding agar pengiriman barang ekspor maupun penerimaan barang impor dapat terlaksana dengan mudah (Sutedi, 2014). Sedangkan pendapat yang kontra mengenai jasa freight forwarding adalah eksportir maupun importir dapat mengekspor atau mengimpor sendiri tanpa menggunakan jasa freight forwarding, tetapi dengan syarat eksportir maupun importir harus memiliki izin untuk melaksanakan kepengurusan dokumen dari pihak Bea dan Cukai yang nantinya disebut sebagai Perusahaan Pengurusan Jasa Kepabeanan (PPJK) (Susilo, 2013).

Akan tetapi dengan menggunakan jasa freight forwarding, eksportir maupun importir lebih mendapatkan manfaatnya dibanding dengan kerugiannya. Karena dengan menggunakan jasa freight forwarding, pihak eksportir maupun importir dapat meminimalisasi tingkat risiko dan kekeliruan serta kesalahan yang nantinya dapat menjadi hambatan dan masalah dalam kegiatan bisnis internasional. Berangkat dari permasalahan yang telah diuraikan oleh 
kami di atas, maka kami tertarik untuk melakukan penelitian tentang prosedur impor yang dilakukan oleh perusahaan freight forwarding serta hambatan-hambatan yang terjadi selama proses impor.

Berdasarkan uraian yang telah dipaparkan pada latar belakang di atas tujuan dilakukannya penelitian ini di antaranya untuk mengetahui prosedur impor dan penerbitan dokumen impor pada PPJK PT. Glorious Interbuana; mengetahui prosedur penerimaan barang impor dari pelabuhan muat dengan status peti kemas full container load (FCL) terms CIF pada PPJK PT. Glorious Interbuana; mengetahui dan mengungkapkan hambatan-hambatan yang dihadapi PPJK PT. Glorious Interbuana dalam penerimaan barang impor dari pelabuhan muat dengan status peti kemas full container load (FCL) terms CIF.

\section{Perdagangan Internasional}

\section{TINJAUAN PUSTAKA}

Aktivitas perekonomian antar penduduk suatu negara dengan penduduk di negara lain dinamakan perdagangan internasional. Dalam hal ini terdapat kesepakatan tertentu yang disepakati bersama (Feriyanto, 2015). Selain itu perdagangan internasional merupakan suatu proses tukar-menukar barang dan jasa yang didasarkan atas kehendak sukarela dari masing-masing negara untuk mendapatkan manfaat perdagangan atau gains off tride. Perdagangan internasional ini melakukan transaksi jual-beli barang dan jasa ke luar negeri, kalau kita membeli barang dan jasa dari luar negeri disebut impor sedangkan kalau kita menjual barang dan jasa ke luar negeri disebut ekspor.

Jika dibandingkan dengan aktivitas perdagangan domestik, maka perdagangan internasional sangatlah rumit dan kompleks yang dapat disebabkan oleh beberapa faktor yaitu keberadaan pembeli dan penjual terpisah oleh batas-batas negara; barang harus dikirim dan diangkut dari suatu negara ke negara lain melalui bermacam regulasi seperti pabean; terdapat perbedaan dalam bahasa, mata uang, taksiran dan timbangan, hukum dalam perdagangan dan sebagainya antar negara satu dengan yang lainnya. Sehingga dapat disimupulkan, perdagangan internasional adalah suatu kegiatan perekonomian dengan mengirim barang ke luar negeri atau menerima barang dari luar negeri dengan ketentuan hukum yang berlaku dengan tujuan untuk memenuhi kebutuhan di dalam negeri dan meningkatkan keuntungan semaksimal mungkin.

Dalam perdagangan internasional dikenal beberapa teori, di antaranya teori keunggulan mutlak (absolute advantage), teori keunggulan komparatif, teori permintaan timbal balik (reciprocal demand), dan pandangan kaum merkantilisme. Adapun alasan yang menjadi penyebab terjadinya perdagangan internasional adalah revolusi informasi dan transportasi, interdependensi kebutuhan, liberalisasi ekonomi, kebutuhan devisa, adanya perbedaan selera, adanya keanekaragaman dalam proses produksi, perbedaan kebudayaan dan gaya hidup (Feriyanto, 2015).

Banyak pihak yang terlibat dalam transaksi perdagangan internasional di antaranya pihak eksportir, pihak importir, pihak indentor, pihak promosi dan pihak penunjang yang terdiri dari badan usaha transportasi, bank devisa, maskapai pelayaran, perusahaan asuransi, kantor perwakilan atau kedutaan, surveyor, dan kepabeanan.

\section{Dokumen-Dokumen Perdagangan Internasional}

Dokumen yang terdapat dalam kegiatan ekspor-impor terdiri dari dua jenis yaitu dokumen induk dan dokumen penunjang. Kedua dokumen ini mempunyai peran yang sangat penting dalam kesuksesan kegiatan eksporimpor. Dokumen induk merupakan dokumen utama yang diterbitkan Badan Pelaksana Utama Perdagangan Internasional yang berfungsi sebagai instrumen legalitas transaksi perdagangan internasional. Dokumen yang termasuk dalam dokumen induk adalah Letter of Credit (L/C), Bill of Lading (B/L), Faktur (Invoice), Dokumen (Polis) Asuransi. Adapun dokumen penunjang merupakan dokumen pelengkap sebagai rincian keterangan dokumen induk. Dokumen yang termasuk kedalam dokumen penunjang adalah Daftar Pengepakan (Packing List), Surat Keterangan Asal (Certificate Of Origin), Surat Keterangan Pemeriksaan (Certificate Of Inspection), Seritifikat Mutu (Certificate Of Quality), Sertifikat Mutu dari Produsen (Manufacture's Quality Certificate), Keterangan Timbangan (Weight Note), Daftar Ukuran (Measurement List), Analisis Kimia (Chemical Analysis), Wesel (Bill Of Exchange).

\section{Impor}

Impor memiliki pengertian, dasar hukum, perizinan, tatalaksana, klasifikasi dan batasan. Menurut Tandjung (2011) dan Susilo (2008), impor merupakan kegiatan memasukkan barang dari luar daerah pabean Indonesia ke daerah pabean Indonesia sesuai dengan regulasi pemerintah yang berlaku. Dengan demikian, minimal terdapat dua 
negara dalam melakukan kegiatan impor. Purnamawati dan Fatmawati (2013) menambahkan bahwa kegiatan impor merupakan kegiatan membeli barang-barang dari negara luar sesuai dengan aturan pemerintah dengan menggunakan valuta asing yang berlaku di negara tersebut. Sehingga, dapat disimpulkan bahwa impor yaitu kegiatan perdagangan internasional dengan cara memasukkan barang ke wilayah pabean Indonesia yang dilakukan oleh perorangan atau perusahaan yang bergerak dibidang ekspor impor dengan mematuhi ketentuan peraturan perundang-undangan yang berlaku yang dikenakan bea masuk.

\section{Freight Forwarding}

Freight forwading adalah badan usaha yang bertujuan untuk memberikan jasa pengurusan dokumen administrasi yang diperlukan dalam kegiatan perdagangan internasional (Suyono, 2005) dan berperan utama sebagai perantara antara shipper (eksportir) dan consignee (importir) (Susilo, 2008). Sehingga, dapat disimpulkan bahwa Freight forwarding merupakan badan usaha atau perusahaan jasa yang memberikan servis pelayanan dalam kegiatan perdagangan internasional dalam pengiriman, pengangkutan dan penerimaan barang dengan menggunakan multimodal transport melalui darat, laut maupun udara. Dalam perdagangan internasional banyak sekali yang berperan dalam melakukan kegiatan operasionalnya yang membuat perannya begitu penting dalam setiap tahapan, salah satunya adalah freight forwarding (Hamdani, 2003). Freight forwarding dalam peranannya terbagi menjadi empat bagian antara lain sebagai prinsipal, perencana pengelola pengangkutan, pemasaran sebuah perusahaan dan pengurusan prosedur dan formalitas dokumentasi.

Dalam pengangkutan kontainer dari suatu negara ke negara lainnya terdapat dua jenis status pengiriman yaitu Full Container Load (FCL) dan Less Than Container Load (LCL). Pengangkutan jenis FCL merupakan pengangkutan satu atau lebih dari satu kontainer penuh yang berasal dari satu shipper (eksportir) dan ditujukan kepada satu consignee (importir).

\section{Incoterms}

Incoterms diterapkan dengan suatu jumlah kewajiban yang dikenali yang ditetapkan pada pihak-pihaknya, seperti misalnya kewajiban penjual untuk menempatkan barang pada tempat yang ditentukan pembeli, atau menyerahkan suatu barang itu untuk segera diadakan pengangkutan atau mengantar barang tadi pada suatu tujuan serta dengan distribusi risiko di antara para pihak yang terikat dalam perjanjian pengangkutan. Tujuan dari Incoterms adalah untuk menyediakan seperangkat aturan internasional bagi penafsiran ketentuan perdagangan yang secara umum banyak digunakan dalam perdagangan luar negeri. Dengan demikian, ketidakpastian akibat perbedaan penafsiran ketentuan di negara-negara yang berbeda dapat dihindari atau setidaknya dikurangi hingga suatu tingkatan yang dapat dipertimbangkan.

Dalam Incoterms 2010, terms of delivery ada 11 macam, tetapi pada umumnya ada 4 terms of delivery yang biasa digunakan yaitu:

a. $\quad$ EXW $=>$ Ex Works (...nama tempat)

b. $\quad \mathrm{FOB}=>$ Free On Board (...nama pelabuhan muat)

c. $\quad \mathrm{CFR}=>$ Cost and Freight (...nama pelabuhan tujuan)

d. $\quad \mathrm{CIF}=>$ Cost Insurance and Freight (...nama pelabuhan tujuan)

\section{Penelitian Sebelumnya}

Untuk dapat menguatkan hasil penelitian kami, diperlukan beberapa artikel jurnal untuk dapat dibandingkan dengan hasil penelitian kami agar dapat ditemukan kesamaan dan perbedaannya. Berikut uraian penjelasan mengenai penelitian sebelumnya yang dilakukan peneliti lain yang memiliki kesamaan topik dengan hasil penelitian kami. 
Tabel 1. Penelitian Sebelumnya

\begin{tabular}{|c|c|c|c|}
\hline No & $\begin{array}{c}\text { Penulis } \\
\text { dan } \\
\text { Tahun }\end{array}$ & $\begin{array}{c}\text { Metode } \\
\text { Penelitian }\end{array}$ & Hasil \\
\hline 1 & $\begin{array}{l}\text { (Nugroh } \\
\text { o, 2006) }\end{array}$ & Studi Kasus & $\begin{array}{l}\text { Prosedur impor yang diterapkan oleh PT. Segaramas Senaputera yang pertama } \\
\text { adalah mendapatkan surat kuasa, faktur, daftar pengepakan, polis asuransi, second } \\
\text { Bill of Lading dari importir (PT. Lembah Tidar Jaya Leater Industri). Hambatan } \\
\text { yang terjadi adalah jumlah karyawan tidak sesuai berdasarkan beban kerja, } \\
\text { pengurusan dokumen biaya yang tinggi serta keterbatasan dalam sarana dan } \\
\text { prasarana operasional perusahaan. }\end{array}$ \\
\hline 2 & $\begin{array}{l}\text { (Wibowo } \\
\text {, 2008) }\end{array}$ & $\begin{array}{l}\text { Metode } \\
\text { Deskriptif }\end{array}$ & $\begin{array}{l}\text { Tatalaksana impor pada PT ASIAMAJU SELARAS diawali dengan kegiatan } \\
\text { pemesanan barang, memberikan proforma invoice, penunjukan surveyor, } \\
\text { penerimaan dokumen pengapalan, penerimaan pemberitahuan kedatangan kapal, } \\
\text { pengurusan dokumen melalui PPJK, dan pembayaran. }\end{array}$ \\
\hline 3 & $\begin{array}{l}\text { (Pahlevi, } \\
\text { 2011) }\end{array}$ & $\begin{array}{l}\text { Analisis } \\
\text { Deskriptif }\end{array}$ & $\begin{array}{l}\text { Kesimpulan yang dapat ditarik bahwa prosedur impor barang bahan baku glucose } \\
\text { syrup adalah prosedur impor glukosa yang termasuk kategori bahan-bahan pangan } \\
\text { yang berisiko tinggi untuk disalahgunakan. Sehingga dokumen-dokumen yang } \\
\text { diperlukan harus sesuai dengan keterangan dan jenis barang dan impor glukosa } \\
\text { merupakan suatu proses impor yang harus melalui pemeriksaan fisik oleh Bea } \\
\text { Cukai di jalur merah. }\end{array}$ \\
\hline 4 & $\begin{array}{l}\text { (Antona, } \\
\text { 2014) }\end{array}$ & $\begin{array}{l}\text { Metode } \\
\text { Deskriptif }\end{array}$ & $\begin{array}{l}\text { Dokumen yang digunakan dalam prosedur impor komponen bogie kereta api pada } \\
\text { PT. Industri Kereta Api (INKA) Madiun antara lain meliputi : faktur, bill of } \\
\text { lading, polis asuransi, letter of credit, daftar pengepakan, surat kuasa, daftar } \\
\text { timbangan daftar analis kimia, sertifikat keterangan asal. Selain dari dokumen- } \\
\text { dokumen yang di atas diperlukan juga dokumen lainnya yang terdiri dari, Delivery } \\
\text { Order (D/O), Surat Setor Bea Cukai, Pemberitahuan Impor Barang (PIB). }\end{array}$ \\
\hline 5 & $\begin{array}{l}\text { (Astuti, } \\
\text { 2017) }\end{array}$ & $\begin{array}{l}\text { Metode } \\
\text { Deskriptif } \\
\text { Kualitatif }\end{array}$ & $\begin{array}{l}\text { Berdasarkan dari hasil yang diperoleh dari pengamatan yang telah dilakukan kami } \\
\text { yaitu prosedur impor pengadaan suku cadang mesin dimulai dari permintaan yang } \\
\text { dilakukan oleh user. Selanjutnya Manajer Logistik menerima permintaan harga } \\
\text { dan kuantitas suku cadang mesin, kemudian diteruskan ke bagian pengadaan } 1 \\
\text { untuk melakukan pembelian sampai dengan pembuatan pesanan pembelian yang } \\
\text { kemudian untuk prosedur impor yang dilakukan mengacu kepada prosedur yang } \\
\text { telah diatur dalam INSW. Penyimpanan dan pendistribusian barang (suku cadang) } \\
\text { dilakukan oleh PT Kusumahadi Santoso di Gudang Logistik. }\end{array}$ \\
\hline 6 & $\begin{array}{l}\text { (Wagner, } \\
2016 \text { ) }\end{array}$ & $\begin{array}{l}\text { Deskriptif } \\
\text { Kualitatif }\end{array}$ & $\begin{array}{l}\text { Tulisan ini membahas marjin perdagangan internasional yang sampai sekarang } \\
\text { terbengkalai dengan menyelidiki untuk pertama kalinya frekuensi eksport dan } \\
\text { import Jerman. Impor dan ekspor menunjukkan tingkat kelesuan yang tinggi. Pada } \\
\text { tahun tertentu sekitar separuh dari semua kombinasi perusahaannegara hanya } \\
\text { sekali atau dua kali melakukan perdagangan dengan negara-negara Uni Eropa. } \\
\text { Frekuensi transaksi yang tercatat cenderung menurun seiring dengan } \\
\text { bertambahnya jumlah transaksi per tahun. Model empiris menunjukkan bahwa } \\
\text { untuk Jerman, frekuensi transaksi di tingkat perusahaan-negara baik cenderung } \\
\text { menurun seiring dengan kenaikan biaya per-pengiriman. }\end{array}$ \\
\hline 7 & $\begin{array}{l}\text { (Hellman } \\
\& \\
\text { Kaufman } \\
\text { n, 2002) }\end{array}$ & $\begin{array}{l}\text { Metode } \\
\text { Despriktif } \\
\text { Verifikatif }\end{array}$ & $\begin{array}{l}\text { Masalah korupsi di suatu Negara mengurangi Foreign Direct Investment (FDI). } \\
\text { Pemerintah harus membuat kebijakan terkait FDI yang benar sehingga dapat } \\
\text { mencegah praktik-praktik yang menghambat FDI seperti korupsi. }\end{array}$ \\
\hline
\end{tabular}




\begin{tabular}{lll}
\hline $\mathbf{8}$ & (Mundell & Studi \\
& $, 1957)$ & Empiris
\end{tabular}

$\begin{array}{lll}\text { (Mel, } & \text { Studi } \\ \text { Jayaratne } & \text { Empiris } \\ & \text { \& } & \end{array}$

Premarat

ne, 2011)

$10 \begin{array}{ll}\text { (Edsman, } & \text { Penelitian } \\ 2004) & \text { deskriptif }\end{array}$

Biaya transportasi telah diabaikan dalam teori perdagangan internasional, yang sebagian besar diuraikan pada asumsi bahwa biaya transportasi tidak ada. Dalam tulisan ini akan disajikan metode geometrik sederhana untuk menggambarkan biaya transportasi dalam diagram kurva penawaran, dan menerapkan metode ini untuk mempertimbangkan efek biaya transportasi pada ketentuan perdagangan, masalah transfer, tarif optimal, dan pengembalian faktor riil.

Untuk menghindari mengenalkan industri ketiga - industri transportasi - perlu menggunakan asumsi drastis, namun sangat berguna mengenai sifat biaya transportasi. Kami berasumsi bahwa biaya transportasi dipenuhi oleh pemborosan sebagian barang yang diperdagangkan. Asumsi ini berarti bahwa: jika setiap negara menyediakan sumber daya untuk mengangkut ekspornya sendiri, maka hanya sebagian barang yang diekspor akan diterima sebagai impor oleh negara lain, sisanya digunakan sebagai biaya transportasi; jika setiap negara menyediakan sumber daya untuk mengangkut impornya, maka sebagian dari ekspornya akan digunakan untuk setiap unit barang impor negara lain; dan jika masing-masing negara berbagi pengangkutan setiap barang, beberapa sumber daya masingmasing negara akan habis untuk mengangkut masing-masing barang.

Transaksi perdagangan internasional melibatkan banyak pihak yang harus bertindak koordinasi yang efektif dan efisien di antara mereka. Sementara perusahaan individu dan individu dapat melakukan tindakan tertentu dalam hal ini, beberapa harus dilakukan di tingkat negara. Badan yang diakui secara global menerbitkan indikator fasilitasi perdagangan yang memberi para pembuat kebijakan dan masyarakat umum untuk menilai dan menganalisis tingkat fasilitasi perdagangan suatu negara. Namun, pemahaman yang lebih dalam tentang proses perdagangan diperlukan untuk mengidentifikasi area yang menciptakan kemacetan dalam perdagangan dan untuk mengambil tindakan. untuk meminimalkannya.

Mayoritas perusahaan yang diwawancarai telah lama berkecimpung dalam bisnis dan memiliki Customs House Agents / freight forwarder yang berpengalaman dalam proses / prosedur. Di satu sisi, para pedagang tampaknya telah menjadi aklimatisasi terhadap proses. Namun demikian, mereka mengidentifikasi kebutuhan untuk mengotomatisasi prosedur perdagangan sebagai area prioritas yang perlu perhatian. Tidak ada perbedaan besar dalam hal proses atau waktu yang diambil antara pedagang besar dan UKM. Wawancara menunjukkan bahwa perusahaan BOI memiliki beberapa keuntungan dalam hal waktu yang dibutuhkan untuk berdagang.

Penelitian ini membahas mengenai pentingnya peraturan impor terutama untuk barang impor tententu seperti udang sungai. Ketidakadaan aturan dalam impor dapat menyebabkan punahnya suatu hewan dan mengganggu ekosistem.

\section{METODE PENELITIAN}

Penelitian ini menggunakan metode studi kasus yang merupakan metode yang menggambarkan kejadian, proses, kegiatan atau grup individu tertentu (Creswell, 2010). Metode ini juga memberikan penjelasan mengenai seperti apa dan mengapa suatu kejadian tersebut terjadi (Yin, 2011). Metode ini bukan sekedar untuik menjawab pertanyaan 'what' namun juga untuk menjawab pertanyaan ' $h o w$ ' dan ' why' dari suatu peristiwa. Dilihat dari jenisnya penelitian ini merupakan penelitian deskriptif yang menggambarkan variabel-variabel dengan tanpa melihat korelasinya (Hidayat, 2012). Data yang dipakai dalam penelitian ini yaitu data primer yang merupakan data yang dikumpulkan dan diolah sendiri oleh peniliti langsung dari responden dan juga data sekunder yang merupakan data dalam bentuk sudah jadi, yaitu yang telah diolah dan disajikan oleh pihak lain. 
Teknik pengumpulan datanya melalui observasi pasrtisipan (participant observation), yaitu dengan cara mengamati langsung pada objek yang diteliti (Supriyanto, 2009). Dalam hal ini, kami langsung mengamati dan mempraktikan kegiatan yang dilakukan oleh PT. Glorious Interbuana, khususnya dalam penerimaan barang impor dari pelabuhan muat dengan status peti kemas full container load (FCL) terms CIF. Selain itu, juga digunakan wawancara (interview), yaitu dengan melalui tanya jawab langsung (Supriyanto, 2009), baik dengan pimpinan perusahaan maupun kepala bagian dan atau pihak yang mewakilinya, terutama yang berkaitan dengan prosedur penerimaan barang impor. Selain itu, penelitian ini juga dilakukan studi kepustakaan yang berasal dari artikel jurnal, buku dan yang lainnya. Pengumpulan data primer dalam penelitian ini dilakukan di PT. Glorious Interbuana yang beralamat di Jalan Medan Blok C, Marunda, Cilincing, Jakarta Utara 14120, DKI Jakarta, Indonesia selama satu bulan terhitung sejak tanggal Februari 2018 sampai dengan Maret 2018.

\section{HASIL DAN PEMBAHASAN}

\section{Prosedur Impor dan Penerbitan Dokumen Impor Pada PPJK PT. Glorious Interbuana}

Selama kami melaksanakan kegiatan magang di PPJK PT. Glorious Interbuana, kami mempelajari prosedur impor dan penerbitan dokumen impor yang dilakukan oleh PPJK PT. Glorious Interbuana. Berikut ini prosedur impor pada PPJK PT. Glorious Interbuana:

1. Mendapatkan dokumen dari importir/consignee (Bill of Lading, Invoice, Packing List, Certificate of Origin, Notice of Arrival);

2. Membuat draft Pemberitahuan Impor Barang (PIB);

3. Draft PIB dikirim ke importir untuk dicek ketepatannya sesuai dengan dokumen-dokumen yang dikirim importir sebelumnya;

4. Menunggu kapal sandar/tiba di pelabuhan Tanjung Priuk;

5. Mendapat data manifest BC 1.1;

6. Mengirim/mentransfer Pemberitahuan Impor Barang (PIB) ke bea cukai;

7. Mendapat respon e-billing;

8. E-billing dikirim ke importir;

9. Pihak importir membayar Pajak Dalam Rangka Impor (PDRI);

10. Sistem CEISA (Customs-Excise Information System and Automation) Bea Cukai menerbitkan penjaluran impor (merah, kuning, hijau);

11. Pihak importir/PPJK melakukan pengurusan atas penjaluran bea cukai sampai selesai;

12. Bea Cukai akan menerbitkan Surat Perintah Pengeluaran Barang (SPPB);

13. PT. Glorious Interbuana melakukan proses pembuatan SP 2/Tila (Pembayaran Setorit Pelabuhan Gerakan, dan lain-lain);

14. SP 2 diserahkan ke divisi trucking untuk penarikan kontainer;

15. Proses pengiriman kontainer dari pelabuhan ke gudang/pabrik importir;

16. Pihak importir membuka isi kontainer/stripping;

17. Apabila kontainer sudah kososng, kontainer kosong tersebut dikirim dari pabrik ke depo yang telah ditunjuk;

18. Pihak PPJK PT. Glorious Interbuana meminta Equipment Interchange Receipt (EIR) kontainer untuk diserahkan ke pelayaran;

19. PT. Glorious Interbuana melakukan penarikan jaminan kontainer di pelayaran dan melakukan pengecekan apabila ada biaya reparasi kontainer;

20. PT. Glorious Interbuana melakukan penagihan semua biaya yang terkait dengan kegiatan impor kepada importir.

Meninjau dari penelitian sebelumnya, adapun prosedur impor yang terjadi di PT. Asiamaju Selaras dalam melakukan impor Oli dan Grease diawali dengan korespondensi bisnis, setelah itu melakukan pemesanan barang, memberikan proforma invoice, penunjukan surveyor, penerimaan dokumen pengapalan, penerimaan pemberitahuan kedatangan, pengurusan dokumen melalui PPJK, dan pembayaran (Wibowo, 2008). Dalam penelitian tersebut terdapat beberapa perbedaan dengan penilitian yang kami lakukan di PPJK PT. Glorious Interbuana yaitu dalam hal prosedur impor di mana karena PT. Asiamaju Selaras merupakan perusahaan yang belum memiliki izin untuk 
mengurus kepabeanan dari Bea dan Cukai sehingga prosedur impor mereka serahkan kepada Import Agent/Freight Forwarding.

Selain itu, prosedur impor Komponen Bogie Kereta Api pada PT. Industri Kereta Api (INKA) Madiun pun tidak jauh beda dengan yang terjadi pada PT. Asiamaju Selaras yang meliputi: korespondensi bisnis, setelah itu melakukan pemesanan barang, memberikan proforma invoice, penunjukan surveyor, penerimaan dokumen pengapalan, penerimaan pemberitahuan kedatangan, pengurusan dokumen melalui PPJK, dan pembayaran (Antona, 2014).

Sehingga dapat disimpulkan secara keseluruhan proses impor dapat dimulai dari korespondensi yang dilakukan oleh pihak importir dengan ekspotir, korespondensi bisnis, setelah itu melakukan pemesanan barang, memberikan proforma invoice, penunjukan surveyor, penerimaan dokumen pengapalan, penerimaan pemberitahuan kedatangan, pengurusan dokumen melalui PPJK, dan pembayaran, pembayaran, pengambilan barang impor. Sementara itu, pihak PPJK PT. Glorious Interbuana menerbitkan beberapa dokumen. Berikut ini Prosedur Penerbitan Dokumen Impor oleh PPJK PT. Glorious Interbuana:

1. Setelah pihak importir mengirimkan dokumen (Bill of Lading, Invoice, Packing List, Certificate of Origin) kepada PT. Glorious Interbuana, PT. Glorious Interbuana membuat draft Pemberitahua Impor Barang (PIB) agar diperiksa kembali sesuai dengan dokumen awal (Bill of Lading, Invoice, Packing List, Certificate of Origin);

2. Setelah itu, surat kuasa pengambilan delivery order diserahkan ke maskapai pelayaran;

3. Maskapai pelayaran menerbitkan surat delivery order dan surat pengembalian kontainer;

4. Surat delivery order diserahkan ke pelabuhan untuk pembuatan SP 2/ tila;

5. Surat pengembalian kontainer diserahkan ke depo empty container;

6. Surat pengembalian empty container dan Equipment Interchange Receipt (EIR) yang diterbitkan depo diserahkan ke pelayaran untuk dilakukan pengambilan/penarikan kontainer;

7. Maskapai pelayaran akan melakukan estimasi biaya reparasi apabila ada kerusakan pada kontainer;

8. Apabila tidak ada biaya kerusakan kontainer, pelayaran akan mencairkan jaminan kontainer;

\section{Prosedur Penerimaan Barang Impor dari Pelabuhan Muat dengan Status Peti Kemas Full Container Load (FCL) terms CIF pada PPJK PT Glorious Interbuana}

Berikut di bawah ini Prosedur Penerimaan Barang Impor dari Pelabuhan Muat dengan Status Peti Kemas Full Container Load (FCL) terms CIF pada PPJK PT. Glorious Interbuana:

1. Setelah Pihak importir membayar Pajak Dalam Rangka Impor (PDRI);

2. Selanjutnya, sistem CEISA (Customs-Excise Information System and Automation) Bea Cukai menerbitkan penjaluran impor (merah, kuning, hijau);

3. Pihak importir/PPJK melakukan pengurusan atas penjaluran bea cukai sampai selesai;

4. Bea Cukai akan menerbitkan Surat Perintah Pengeluaran Barang (SPPB);

5. PT. Glorious Interbuana melakukan proses pembuatan SP 2/Tila (Pembayaran Setorit Pelabuhan Gerakan, dan lain-lain);

6. SP 2 diserahkan ke divisi trucking untuk penarikan kontainer;

7. Proses pengeriman kontainer dari pelabuhan ke gudang/pabrik importir;

8. Pihak importir membuka isi kontainer/stripping;

9. Apabila kontainer sudah kososng, kontainer kosong dikirim dari pabrik ke depo yang telah ditunjuk;

10. Pihak PPJK PT. Glorious Interbuana meminta Equipment Interhange Receipt (EIR) kontainer untuk diserahkan ke maskapai pelayaran;

11. PT. Glorious Interbuana melakukan penarikan jaminan kontainer di pelayaran dan melakukan pengecekan apabila ada biaya reparasi kontainer;

12. PT. Glorious Interbuana melakukan penagihan semua biaya yang terkait dengan kegiatan impor kepada importir.

Jika ditinjau dari penelitian sebelumnya yang terjadi pada prosedur impor pengadaan suku cadang mesin di PT. Kusumahadi Santoso Karanganyar dimulai dari permintaan yang dilakukan oleh user. Kemudian Manajer Logistik menerima permintaan harga dan kuantitas suku cadang mesin, kemudian diteruskan ke bagian pengadaan I untuk melakukan pembelian sampai dengan pembuatan pesanan pembelian yang kemudian untuk prosedur impor 
yang dilakukan berdasarkan prosedur yang telah diatur dalam INSW. Penyimpanan dan pendistribusian barang (suku cadang) dilakukan oleh PT. Kusumahadi Santoso di Gudang Logistik (Astuti, 2017).

\section{Hambatan-hambatan yang Dihadapi PPJK PT. Glorious Interbuana dalam Penerimaan Barang Impor dari Pelabuhan Muat dengan Status Peti Kemas Full Container Load (FCL) terms CIF}

Dalam proses penerimaan barang impor dari pelabuhan muat dengan status peti kemas Full Container Load terms CIF terdapat hambatan-hambatan yang dihadapi yaitu:

1. Peraturan Bea dan Cukai yang berubah-ubah

2. Lemahnya hubungan antra instansi kementrian pemerintah dengan bea cukai

3. Proses perizinan yang tidak satu pintu

4. Terlambatnya peneriman dokumen orginal (Bill of Lading, Invoice, dan lain-lain)

5. Importir tidak segera bayar pajak dalam rangka impor sehingga proses pengeluaran kontainer di pelabuhan lama

6. Apabila kontainer terkena OB (Over Brengen)/ gudang tempat penimbunan sementara tidak beroperasi 24 jam sehingga terjadi keterlambatan penarikan kontainer dari pelabuhan

7. Penerbitan Surat Persetujuan Pengeluaran Barang tidak bisa diprediksi sehingga PPJK PT. Glorious Interbuana sering terjadi kendala untuk menyiapkan armada truck untuk melakukan proses penarikan kontainer

8. Beberapa pabrik importir tidak beroperasi 24 jam sehingga apabila terjadi keterlambatan penarikan kontainer maka proses pengeluaran barang dari dalam kontainer akan dilakukan pada hari berikutnya.

9. Delivery Order dari pelayaran ada batas waktu kadaluarsanya, apabila sudah kadaluarsa kontainer tidak bisa ditarik dari pelabuhan atau empty container tidak bisa dibalikan ke depo

Dalam penerimaan barang impor dari pelabuhan muat tentunya mengalami beberap proses yang cukup panjang. Begitu barang sudah tiba di pelabuhan tujuan, maka akan dilakukanlah penjaluran. Hal ini pun dialami oleh PT. Jasco Logistics Semarang dalam mengimpor bahan baku Glucose Syrup di mana barang tersebut termasuk kategori bahan-bahan pangan yang berisiko tinggi untuk disalahgunakan. Sehingga dokumen-dokumen yang diperlukan harus sesuai dengan keterangan dan jenis barang dan impor glukosa merupakan suatu proses impor yang harus melalui pemeriksaan fisik oleh Bea Cukai di jalur merah. Impor glukosa yang melewati jalur merah wajib dilengkapi dokumen di antaranya, Surat Kuasa Impor, Invoice (dibedakan menjadi 3 macam: Proforma Invoice, Commercial Invoice, Consular Invoice), Packing List, Pemberitahuan Impor Barang (PIB), Delivery Order, Job Order, Surat Setoran Pabean Cukai dan Pajak (SSPCP), Bill of Lading (B/L), Surat Badan POM RI, Surat Keterangan Jalan. Sementara dokumen yang digunakan sebagai pelengkap adalah SPJM dan SPPB, agar barang bisa dapat dikeluarkandan dikirim ke tangan importir (Pahlevi, 2011).

Tidak hanya terjadi di Indonesia, di negara lain pun dalam melakukan perdagangan internasional khususnya impor juga mengalami beberapa kendala dan hambatan. Hal itupun terjadi di negara Jerman, frekuensi eksportir dan importir Jerman memperdagangkan barang yang diberikan dengan negara tertentu. Impor dan ekspor menunjukkan tingkat kelesuan yang tinggi. Pada tahun 2014 sekitar separuh dari semua kombinasi perusahaan-negara-baik dicatat hanya sekali atau dua kali untuk perdagangan dengan negara-negara Uni Eropa, dan ini adalah kasus untuk lebih dari 60 persen dari semua kombinasi perusahaan-negara-baik dalam perdagangan dengan non- Negara-negara Uni Eropa. Frekuensi transaksi yang tercatat cenderung menurun seiring dengan bertambahnya jumlah transaksi per tahun. Hal ini sesuai dengan adanya biaya tetap per-kiriman yang memberi insentif bagi perusahaan dagang untuk melakukan transaksi lintas batas yang jarang. Model empiris menunjukkan bahwa untuk Jerman, frekuensi transaksi di tingkat perusahaan-negara baik cenderung menurun seiring dengan kenaikan biaya per-pengiriman bila karakteristik perusahaan dan barang yang tidak diawasi (Wagner, 2016).

\section{Kesimpulan dan Saran}

\section{PENUTUP}

Prosedur Penerimaan Barang Impor dari Pelabuhan Muat dengan Status Peti Kemas Full Container Load (FCL) terms CIF pada PPJK PT Glorious Interbuana dimulai setelah Pihak importir membayar Pajak Dalam Rangka Impor (PDRI); Selanjutnya, sistem CEISA (Customs-Excise Information System and Automation) Bea Cukai menerbitkan penjaluran impor (merah, kuning, hijau); Pihak importir/PPJK melakukan pengurusan atas penjaluran bea cukai sampai selesai; Bea Cukai akan menerbitkan Surat Perintah Pengeluaran Barang (SPPB); PT. Glorious Interbuana melakukan proses pembuatan SP2/Tila (Pembayaran Setorit Pelabuhan Gerakan, dan lain-lain); SP 2 diserahkan ke 
divisi trucking untuk penarikan container; Proses pengeriman container dari pelabuhan ke gudang/pabrik importir; Pihak importir membuka isi container/stripping; Apabila container udah kososng, container kosong dikirim dari pabrik ke depo yang telah ditunjuk; Pihak PPJK PT. Glorious Interbuana meminta Equipment Interhange Receipt (EIR) container untuk diserahkan ke maskapai pelayaran; PT. Glorious Interbuana melakukan penarikan jaminan container di pelayaran dan melakukan pengecekan apabila ada biaya reparasi container; PT. Glorious Interbuana melakukan penagihan semua biaya yang terkait dengan kegiatan impor kepada importir.

Dalam menjalankan aktivitas perdagangan internasional tentunya PT. Glorious Interbuana mengalami beberapa kendala dan hambatan. Hambatan-hambatan yang dihadapi PPJK PT. Glorious Interbuana dalam Penerimaan Barang Impor dari Pelabuhan Muat dengan Status Peti Kemas Full Container Load (FCL) terms CIF antara lain yaitu peraturan Bea dan Cukai yang berubah-ubah; lemahnya hubungan antara instansi kementrian pemerintah dengan bea cukai; proses perizinan yang tidak satu pintu; terlambatnya peneriman dokumen orginal (Bill of Lading, Invoice, dan lain-lain); importir tidak segera bayar pajak dalam rangka impor sehingga proses pengeluaran kontainer di pelabuhan lama; apabila kontainer terkena OB (Over Brengen)/ gudang tempat penimbunan sementara tidak beroperasi 24 jam sehingga terjadi keterlambatan penarikan kontainer dari pelabuhan; penerbitan Surat Persetujuan Pengeluaran Barang tidak bisa diprediksi sehingga PPJK PT. Glorious Interbuana sering terjadi kendala untuk menyiapkan armada truck untuk melakukan proses penarikan kontainer; beberapa pabrik importir tidak beroperasi 24 jam sehingga apabila terjadi keterlambatan penarikan kontainer maka proses pengeluaran barang dari dalam kontainer akan dilakukan pada hari berikutnya; delivery order dari pelayaran ada batas waktu kadaluarsanya, apabila sudah kadaluarsa kontainer tidak bisa ditarik dari pelabuhan atau empty container tidak bisa dibalikan ke depo.

Berdasarkan data dari PT. Glorious Interbuana, para importir dalam melakukan perdagangan internasional lebih sering menggunakan kontainer dengan status peti kemas Full Container Load (FCL) dibandingkan dengan Less Than Container Load (LCL). Hal ini disebabkan karena para importir dalam membeli barang biasanya dalam jumlah yang cukup banyak. PT. Glorious Interbuana dalam melakukan perdagangan internasional lebih sering melakukan ekspor dibandingkan impor, disebabkan impor lebih mengeluarkan modal yang sangat besar dan banyak dibanding dengan kegiatan ekspor. Pada dasarnya penelitian ini mengambil status peti kemas Full Container Load (FCL) dengan terms CIF disebabkan kebanyakan importir lebih menggunakan container dengan status FCL dibanding dengan LCL dengan terms CIF dibanding dengan terms lainnya yang terjadi pada PPJK PT. Glorious Interbuana.

Dalam melakukan perdagangan internasional, PT. Glorious Interbuana sudah melakukan dengan cukup baik berdasarkan Standard Operational Procedure yang berlaku. Namun, ada beberapa hal yang perlu diperbaiki agar proses perdagangan internasional berjalan dengan lancar, yaitu transparasi informasi peraturan dan juga sosialisasi dari pihak bea cukai kepada masyarakat, koordinasi antar instansi pemerintah dengan pelaku perdagangan internasional harus jelas sehingga birokrasi dapat dipermudah. Pihak perusahaan yang akan mengimpor barang agar tidak terlambat dalam membuat dan mengirimkan dokumen-dokumen (Bill of Lading, Invoice, Packing List) kepada PPJK PT. Glorious Interbuana agar kegiatan impor tidak mengalami keterlambatan. Jika E-billing telah keluarkan, pihak importir segera membayar pajak dalam rangka impor agar proses pengeluaran container di pelabuhan tidak berlangsung lama. Pihak bea cukai sebaiknya memberitahukan maksimal waktu pengeluaran SPPB, agar pihak PPJK dapat menyiapkan container lebih awal. Agar tidak terjadi keterlambatan, pihak PPJK PT. Glorious Interbuana membuat estimasi waktu jadwal pembukaan dan penutupan kapal agar bisa meminimalisasi keterlambatan penerimaan barang impor. Pada dasarnya, semua pihak yang terkait dalam perdagangan internasional haruslah paham akan hak dan kewajibannya agar masing-masing bisa mendapatkan keuntungan dari kegiatan perdagangan internasional.

\section{DAFTAR PUSTAKA}

Antona, D. (2014). Prosedur Impor Komponen Bogie Kereta Api pada PT. Industri Kereta Api (INKA) Madiun. Surakarta.

Astuti, N. D. (2017). Prosedur Impor Pengadaan Suku Cadang Mesin di PT. Kusumahadi Santoso Karanganyar. Surakarta. 
Badan Pusat Statistik Republik Indonesia. (2017, November). Badan Pusat Statistik. Retrieved from https://www.bps.go.id/pressrelease/2017/12/15/1338/nilai-ekspor-indonesia-november-2017-mencapai-us15-28-miliar-dan-nilai-impor-indonesia-november-2017-mencapai-us-15-15-miliar.html

CNBC Indonesia. (2018, Februari). CNBC Indonesia News. Retrieved from https://www.cnbcindonesia.com/news/20180208175806-4-3879/pertumbuhan-ekspor-dan-impor-chinamulai-pulih

Creswell, J. (2010). Research Design : Pendekatan Kualitatif, Kuantitatif, dan Mixed. Yogyakarta: PT Pustaka Pelajar.

Edsman, L. (2004). The Swedish Story About Import of Live Crayfish. Bull. Fr. Pêche Piscic., 372-373, $281-288$. https://doi.org/10.1051/kmae:2004003

Feriyanto, A. (2015). Perdagangan Internasional. Yogyakarta: Pustaka Baru Press.

Hamdani. (2003). Seluk Beluk Perdagangan Ekspor Impor. Jakarta: Yayasan Bina Usaha Niaga Indonesia.

Hellman, J. S., Jones, G., \& Kaufmann, D. (2002). Far from Home: Do Foreign Investors Import Higher Standards of Governance in Transition Economies? SSRN Electronic Journal, 2312(April 2000). https://doi.org/10.2139/ssrn.386900

Hidayat, A. A. (2012). Riset Keperawatan dan Teknik Penulisan Ilmiah. Jakarta: Salemba Medika.

Mel, D. de, Jayaratne, S., \& Premaratne, D. (2011). Improving Import-Export Procedures and Processes in Sri Lanka (Asia-Pacific Research and Training Network on Trade).

Mundell, R. A. (1957). Transport Costs in International Trade Theory. The Canadian Journal of Economics and Political Science, XXIII(3), 331-348. https://doi.org/https://doi.org/10.1017/S0315489000034307

Nugroho, B. T. (2006). Prosedur Impor Drum Salted Head Pieces Pada PT. Segaramas Senaputera Semarang. Surakarta.

Pahlevi, R. B. A. (2011). Prosedur Impor Barang Bahan Baku Glucose Syrup yang Dilakukan oleh PT. Jasco Logistics Semarang. Surakarta.

Purnamawati, A. \& Fatmawati, S. (2013). Dasar - dasar Ekspor Impor. Yogyakarta: UPP STIM YKPN.

Supriyanto. (2009). Metodologi Riset Bisnis. Jakarta: PT. Indeks.

Susilo, A. (2008). Buku Pintar Ekspor - Impor. Jakarta: Trans Media Pustaka.

Susilo, A. (2013). Panduan Pintar Ekspor Impor. Jakarta: TransMedia.

Sutedi, A. (2014). Hukum Ekspor Impor. Jakarta: Penebar Swadaya Grup.

Suyono, C. R. (2005). Shipping (Pengangkutan Internasional Ekspor - Impor melalui Laut). Jakarta: PPM.

Tandjung, M. (2011). Aspek dan Prosedur Ekspor - Impor. Jakarta: Salemba Empat.

Wagner, J. (2016). The lumpiness of German exports and imports of goods. Economics, 10, 1-39. https://doi.org/10.5018/economics-ejournal.ja.2016-21

Wibowo, H. (2008). Prosedur Impor Oli dan Grease pada PT. Asiamaju Selaras di Jakarta. Surakarta.

Yin, R. K. (2011). Studi Kasus : Desain dan Metode. Jakarta: Rajagrafindo Persada. 